
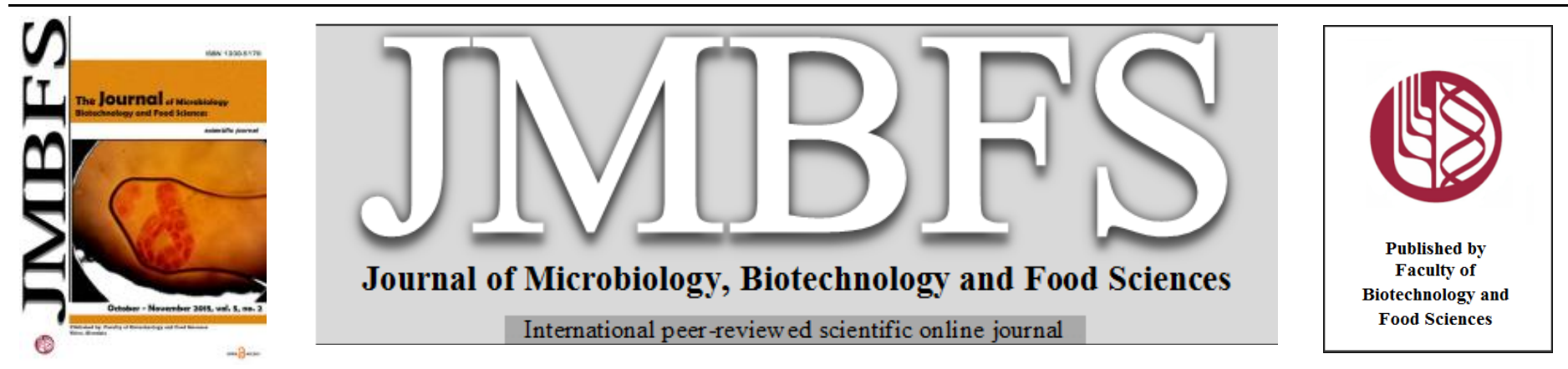

\title{
SUPPLEMENTATION OF FRUIT PROCESSING WASTE FOR ENDOXYLANASE PRODUCTION BY TRICHODERMA KOENINGI ISOLATE AND ITS OPTIMIZATION USING CENTRAL COMPOSITE DESIGN: APPLICATION OF PRODUCED ENDOXYLANASE IN MANGO JUICE CLARIFICATION
}

\author{
Ramesh Bandikari, Sreedharamurthy Mannepula, Rama Mohan Poludasu, Vijaya Sarathi Reddy Obulam*
}

Address(es):

Department of Biochemistry, Sri Venkateswara University, Tirupati - 517 502, India, Phone: +91 8772289485.

*Corresponding author: ovsreddy@yahoo.com

doi: 10.15414/jmbfs.2015.5.2.162-166

\section{ARTICLE INFO}

Received 26. 7. 2014

Revised 25. 6. 2015

Accepted 7. 7. 2015

Published 1. 10. 2015

Regular article open $\partial_{\text {ACCESS }}$

\begin{abstract}
The aim of this study was to optimize the supplementation of custard apple, pomegranate peel along with $\mathrm{KH}_{2} \mathrm{PO}_{4}$, $\left(\mathrm{NH}_{4}\right)_{2} \mathrm{SO}_{4}$ and $\mathrm{MgSO}_{4}$ for maximum endoxylanase production by Trichoderma koeningi isolate on pretreated corn cobs using CCD. Predicted endoxylanase yield was highest $(3242.43 \mathrm{U} / \mathrm{g})$ with the actual yield of $(3107.58 \mathrm{U} / \mathrm{g})$ from $2 \% \mathrm{NaOH}$ pretreated corn cobs. The model predicted $\mathrm{R}^{2}$ value of $0.9147 \%$ indicating that it was appropriate to predict the levels of variables to achieve maximum endoxylanase yield. The produced endoxylanase clarified mango juice of Baneshan and Totapuri varieties at $40^{\circ} \mathrm{C}$ and $56 \mathrm{~h}$. The endoxylanase treatment enhanced the clarity of Baneshan juice by $51.7 \%$ with a release of $121.1 \mathrm{mg} / \mathrm{ml}$ of reducing sugars at an optimized enzyme dose of $9.6 \mathrm{U}$ that led to maximum flow rate of $8 \mathrm{ml} / \mathrm{min}$. In the case of Totapuri juice, there was $43.4 \%$ increase in clarity and release of $102.6 \mathrm{mg} / \mathrm{ml}$ reducing sugars at an optimized enzyme dose of $12.8 \mathrm{U}$ that lead to a maximum juice flow rate of $6 \mathrm{ml} / \mathrm{min}$. The HPLC analysis showed that the hydrolysed products of mango juice were xylose and xylo-oligosacharides. An optimized xylanase production was achieved from low cost agro residues, which results in the reduction of enzyme cost.
\end{abstract}

Keywords: Endoxylanase, CCD, Corn cobs, Mango juice, Clarification

\section{INTRODUCTION}

The plant cell wall is a composite material derived from cellulose, hemicellulose and lignin. Xylan is a major hemicelluloses of plants and accounts for 20-35\% of the total dry weight of lignocellulose in perennial plants. Xylan is composed of a linear polymer of 1,4- $\beta$-linked-D-xylopyranosyl units with side chains of $\mathrm{O}$ acetyl, arabinosyl and methylglucuronosyl substituents (Maheshwari et al., 2000). Lignocellulose is the only renewable carbon source available in large quantities with out any food and feed value. The various sources of lignocelluloses include forest waste, municipal solid waste, fruit and vegetable waste, pulp and paper industry waste and herbaceous energy crops (Jeya $\boldsymbol{e t}$ al., 2009). The raw carbon source has been estimated as the major cost factor for large scale enzyme production.

The huge amount of lignocellulosic biomass generated yearly cause solid waste management and environmental problems. In India, maize is the third most important food crop after rice and wheat. Annual production of maize in India is approximately 21,060,000 million tons. On an average for every $1 \mathrm{~kg}$ of dry corn grains produced, about $0.15 \mathrm{~kg}$ of cobs, $0.22 \mathrm{~kg}$ of leaves and $0.50 \mathrm{~kg}$ of stalks are produced from corn processing (Sokhansanj et al., 2002). In 2011, this resulted in the production of about $130.13,190.85$ and 433.76 million tonnes of cobs, leaves and stalks, respectively. A large quantity of corn cobs generated remains unused as lignocellulosic waste in fields and factories or is used as animal feed (Inglett, 1970). Based on the above assumptions the potential to exploit corn cobs as a cheap carbon source for the production of xylanase is unlimited. The filamentous fungi are industrially important producers of this enzyme due to extracellular release of xylanases and higher yields compared to yeast and bacteria and production of several auxiliary enzymes that are necessary for debranching of the substituted xyalanase (Wang et al., 2003). Xylanase show great potential for industrial applications mainly for the bioconversion of lignocelluloses to sugar, ethanol, clarification of juice and wines, improving the nutritional quality of silage and green feed, and de-inking processes of waste papers (Viikari et al., 2001).

Enzyme productivity in solid state fermentation (SSF) is usually much higher than that of submerged fermentation (SmF) (Khurana et al., 2007). SSF has gained research interest in recent years because of economic and engineering advantages. SSF also employs agricultural residues in their natural form, thus helping to prevent the environmental pollution.

The production of xylanase and other enzymes by fungi is known to be dependent upon the composition of growth medium and fermentation conditions. Therefore, reducing the cost of enzyme production by optimizing the fermentation medium and the process is the goal of basic research for industrial applications (Park et al., 2000). The optimization of fermentation conditions is a serious problem in the development of economically feasible bioprocesses Combinational interactions of culture conditions with the production of the desired compounds are numerous and the optimum processes are to be developed using an effective experimental design procedure. Response surface methodology (RSM), which is a collection of statistical techniques for designing experiments, evaluates the effect of factors and provides an array of optimum conditions for bioprocesses (Latifian et al., 2007, Awafo et al., 2000). RSM has been widely used in the empirical study of the relationship between one or more measured responses such as yield on one hand and a number of input variables such as time, temperature and concentration on the other hand. This is the first study that dwells on the production and optimization of xylanase from T. koeningi.

The objective of our study was to optimize the endoxylanase production by $T$. koeningi isolate on pretreated corn cobs by SSF with fruit peel powder supplementation along with other fermentation parameters using RSM. Further to utilize the produced endoxylanase for the mango juice clarification.

\section{MATERIALS AND METHODS}

\section{Isolation and identification of fungi}

Xylanolytic strain were isolated from sorghum waste decomposing site at Agricultural University, Tirupati and stored at $4{ }^{\circ} \mathrm{C}$ for subsequent studies and named as Trichoderma koeningi with accession number KT006533.

\section{Substrate preparation and sterilization}

The corn cobs were collected from local market and agro-fields, Tirupati, India and thoroughly washed with water and dried in an oven at $70^{\circ} \mathrm{C}$ for $12 \mathrm{~h}$. The dried corncobs were milled, meshed and collected in polythene bags for further 
analysis. The corn cob-powder $(2.0 \mathrm{~g})$ was pretreated sequentially with $10.0 \mathrm{ml}$ of aqueous $2 \% \mathrm{NaOH}(\mathrm{w} / \mathrm{w})$, at $90^{\circ} \mathrm{C}$ for $90 \mathrm{~min}$. The liquid and solid hydrolysates were separated for further experiments.

\section{Fruit peel powder preparation}

The processed custard apple and pomegranate peels were collected and oven dried at $50-60^{\circ} \mathrm{C}$ for $8 \mathrm{~h}$. Dried peels were finely grounded and milled to a particle size of 40 BS (British Standard) mesh in an Apex mill. The fruit peel powders were stored in polythene bags for further analysis.

\section{Analysis of proximate composition of fruit peels}

The components (cellulose, hemicellulose and lignin) of pretreated and untreated substrates were analyzed according to the procedures of Goering and Van Soest (1970). Total dry matter, moisture, ash content, crude fibre, crude fat and crude protein were determined by the procedures of AOAC (1990) methods. Total carbohydrate content was determined by the method of Dubios et al. (1956).

\section{Spore propagation and inoculum preparation}

Spores of the $T$. koeningi were propagated on PDA (Himedia, India) slants at room temperature for 5 days and harvested with sterile distilled water containing $0.1 \%(\mathrm{w} / \mathrm{v})$ Tween 80 . The spore suspension was passed through a $0.5 \mathrm{~mm}$ sieve to eliminate mycelia and media components. The spore numbers were estimated by Romanowska et al. (2006). Ten percent (v/v) of spore suspension $\left(1 \times 10^{8}\right.$ spore $/ \mathrm{ml}$ ) was used as inoculum for SSF process.

\section{Production of xylanase by SSF}

SSF was carried out in Erlenmeyer conical flasks $(250 \mathrm{ml})$ that contained pretreated corncobs as a carbon source $(5 \mathrm{~g})$ and basal medium composition of (g/l): $\mathrm{KH}_{2} \mathrm{PO}_{4}, 2.0 ;\left(\mathrm{NH}_{4}\right)_{2} \mathrm{SO}_{4}, 1.4 ; \mathrm{CaCl}_{2} 2 \mathrm{H}_{2} \mathrm{O}, 0.3 ; \mathrm{MgSO}_{4} 7 \mathrm{H}_{2} \mathrm{O}, 0.3$; urea 0.3 ; Proteose peptone, 0.25 ; Yeast extract, 0.2 ; and trace metal solution, $1 \mathrm{~m}$ $\left[\mathrm{FeSO}_{4} \cdot 7 \mathrm{H}_{2} \mathrm{O}, 5 ; \mathrm{MnSO}_{4} \cdot 7 \mathrm{H}_{2} \mathrm{O}, 5.6 ; \mathrm{ZnSO}_{4} \cdot 7 \mathrm{H}_{2} \mathrm{O}, 3.34 ; \mathrm{CoCl}_{2} 2 \mathrm{H}_{2} \mathrm{O}, 2 \mathrm{mg} / \mathrm{l}\right]$ Tween $80,1 \mathrm{ml}$. Prior to sterilization at $121^{\circ} \mathrm{C}$ for $20 \mathrm{~min}$, the initial $\mathrm{pH}$ of the medium was adjusted to 5.5. The culture medium was then inoculated with a spore suspension $(2.0 \mathrm{ml})$ of 4 day-old culture grown on glucose pre-cultured medium (\%; w/v); (glucose, 1.5 ; yeast extract, $0.4 ; \mathrm{K}_{2} \mathrm{HPO}_{4}, 0.2 ; \mathrm{MgSO}_{4} 7 \mathrm{H}_{2} \mathrm{O}$ $0.1 ; \mathrm{pH} 7.0)$. The moisture content in each flask was adjusted and maintained to $60 \%$ by incubating the flask in a water saturated atmosphere at $30^{\circ} \mathrm{C}$ for 5 days in an incubator. Thereafter, the enzyme was extracted by adding $50 \mathrm{ml}$ of sodium citrate buffer $(50 \mathrm{mM}, \mathrm{pH} 6.0)$ to the flasks and mild shaking on a rotary shaker at $30^{\circ} \mathrm{C}$ for $20 \mathrm{~min}$. The slurry was filtered through a muslin cloth and centrifuged at $10,000 \times \mathrm{g}$ for $10 \mathrm{~min}$. The supernatant was stored at $4^{\circ} \mathrm{C}$ as crude enzyme solution for further analysis.

\section{Enzyme assays}

Xylanase activity in cell free supernatant was determined according to the method of Bailey (1992). Amount of reducing sugars liberated in the DNS method was determined by measuring absorbance at $540 \mathrm{~nm}$ in a UV-vis spectrophotometer using xylose as standard (Miller, 1959). One unit (IU) of xylanase activity was defined as the amount of enzyme that produced $1 \mu \mathrm{mol}$ of xylose equivalent per min in the assay conditions. Cellulase activity (FPase, CMCase and endoglucanase) was determined by similar method using $1 \%(\mathrm{w} / \mathrm{v})$ corresponding substrate and D-glucose as standard. The controls without either enzyme or substrate were run simultaneously.

\section{Experimental design for the optimization of xylanase production}

The experimental design and statistical analysis were performed according to the RSM using Design-expert 8.0.6.1 (Stat-Ease, USA) version software. Analysis of variance (ANOVA) and response surface plots were generated using Designexpert 8.0.6.1. Central composite design (CCD) for five variables and three levels each with four concentric point combinations was used to find the optimum custard apple, pomegranate peel, $\mathrm{KH}_{2} \mathrm{PO}_{4},\left(\mathrm{NH}_{4}\right)_{2} \mathrm{SO}_{4}$ and $\mathrm{MgSO}_{4}$ for the xylanase production (U/gds). RSM makes it possible to represent independent process parameters in quantitative form $(\mathbf{B o x}, \mathbf{1 9 6 0})$.

$$
\mathrm{Y}=\mathrm{b}_{0}+\Sigma \mathrm{b}_{\mathrm{i}} \mathrm{X}_{\mathrm{i}} \Sigma \mathrm{b}_{\mathrm{ii}} \mathrm{X}_{\mathrm{i}}^{2}+\Sigma \mathrm{b}_{\mathrm{ij}} \mathrm{X}_{\mathrm{i}} \mathrm{X}_{\mathrm{j}}
$$

Where $\mathrm{Y}$ is the predicted response (xylanase), $\mathrm{b}_{0}$ is the response function, $\mathrm{X}_{\mathrm{i}}$ and $\mathrm{X}_{\mathrm{j}}$ are experimental coded variables, respectively. These coded variables are related to uncoded variables according to the following equation (2).

$$
X_{i}=\frac{2\left(a_{i}-b_{i}\right)}{d_{i}}
$$

Where $\mathrm{a}_{\mathrm{i}}$ is the variable value in actual units of the $i$ th observations, bi is the mean of highest and the lowest variables, value of $a_{i}$ and $d_{i}$ is the difference between the highest and lowest variable value of $\mathrm{a}_{\mathrm{i}}$. A regression mode containing 5 linear $\left(\mathrm{X}_{\mathrm{i}}\right), 5$ quadratic $\left(\mathrm{X}_{\mathrm{i}}^{2}\right), 10$ interaction $\left(\mathrm{X}_{\mathrm{i}} \mathrm{X}_{\mathrm{j}}\right)$ and $\mathrm{b}_{0}$ block term used. The overall second order polynomial mathematical relationship of the response $\mathrm{Y}$ and the five variables, i.e. custard apple peel, pomegranate peel , $\mathrm{KH}_{2} \mathrm{PO}_{4},\left(\mathrm{NH}_{4}\right)_{2} \mathrm{SO}_{4}$ and $\mathrm{MgSO}_{4}$ can be approximated by the quadratic Eq. (3).

$\mathrm{Y}=\mathrm{b}_{0}+\mathrm{b}_{1} \mathrm{X}_{1}+\mathrm{b}_{2} \mathrm{X}_{2}+\mathrm{b}_{3} \mathrm{X}_{3}+\mathrm{b}_{4} \mathrm{X}_{4}+\mathrm{b}_{5} \mathrm{X}_{5}+\mathrm{b}_{11} \mathrm{X}_{1}^{2}+\mathrm{b}_{22} \mathrm{X}_{2}^{2}+\mathrm{b}_{33} \mathrm{X}_{3}^{2}+\mathrm{b}_{44} \mathrm{X}_{4}^{2}+$ $b_{55} X_{5}^{2}+b_{12} X_{1} X_{2}+b_{13} X_{1} X_{3}+b_{14} X_{1} X_{4}+b_{15} X_{1} X_{5}+b_{23} X_{2} X_{3}+b_{24} X_{2} X_{4}+b_{25} X_{2} X_{5}+$ $\mathrm{b}_{34} \mathrm{X}_{3} \mathrm{X}_{4}+\mathrm{b}_{35} \mathrm{X}_{3} \mathrm{X}_{5}+\mathrm{b}_{45} \mathrm{X}_{4} \mathrm{X}_{5}$

The experimental design for the variables, i.e. custard apple peel $(3-8 \mathrm{~g} / \mathrm{l})$ pomegranate peel (2-6 g/l), $\mathrm{KH}_{2} \mathrm{PO}_{4}(1-3 \mathrm{~g} / \mathrm{l}),\left(\mathrm{NH}_{4}\right)_{2} \mathrm{SO}_{4}$ (5-10 g/l) and $\mathrm{MgSO}_{4}$ (2-6 g/l) were taken for measuring the enzyme activity. The design was applied for selection range of each variable (minimum and maximum), total of 50 experiments were designed by the model and performed. The design consisted of $2^{5} \mathrm{CCD}$ factorial points having eight replicates at the central point and ten axial points $(\alpha)$. Optimized values of five independent variables for maximum activities were determined using a numerical optimization package of Designexpert 8.0.6

\section{Mango juice extraction}

Baneshan and Totapuri mango varieties were collected from local market and washed in hot water and fruit juices were prepared by removing peel and seed manually. The maceration of fruit is done by using a blender. Minimum amount of water was added to facilitate the maceration process as well as to help extract more juice. The maceration process was repeated four times to get a smoothtextured puree.

\section{Optimization of mango juice clarification}

Mango juice of the two varieties was treated with xylanase in different doses of 3, 6, 9 and $12 \mathrm{U}$ at optimized temperature and time. At the end of the xylanase treatment, the enzyme in the sample was inactivated by heating the suspension at $90^{\circ} \mathrm{C}$ for $2 \mathrm{~min}$. the treated juices were centrifuged at $3000 \times \mathrm{g}$ for $10 \mathrm{~min}$ and the supernatant was collected. The juice clarification $(50 \mathrm{ml})$ was carried out at 35 , 40,45 and $50^{\circ} \mathrm{C}$ by recording transmittance at $650 \mathrm{~nm}$ taking distilled water $2 \mathrm{ml}$ of sample after every 4 to $52 \mathrm{~h}$. Percentage (\%) clarification of mango juice was calculated as

(\%) Clarification $=\mathrm{X}_{\mathrm{t}}-\mathrm{X}_{\mathrm{c}} / \mathrm{X}_{\mathrm{c}} \times 100\left(\mathrm{X}_{\mathrm{t}}=\right.$ Transmittance of test; $\mathrm{X}_{\mathrm{c}}=$ Transmittance of control)

\section{Filterability and clarity}

The centrifuged juice was tested by filtering $2 \mathrm{ml}$ of juice clarified by different enzyme dose through a filter paper (Whatman No. 1) and comparing its value by flow rate of control. The clarity of the juice obtained was determined by measuring the absorbance at a wavelength of $660 \mathrm{~nm}$ using UV-Vis spectrophotometer using distilled water as reference.

\section{Reducing sugars and total titratable acidity}

Reducing sugars released after the enzymatic treatment were determined through Bailey (1992) method using DNS reagent (Miller, 1959). The total titratable acidity was determined by titrating $15 \mathrm{ml}$ of diluted juice (20:80; distilled water) with $0.1 \mathrm{~N} \mathrm{NaOH}$. The acidity value was calculated as malic acid equivalent.

\section{HPLC analysis of xylanase treated mango juice (sugars)}

The mango juices were analyzed on a Dionex DX-600 series liquid chromatograph (HPLC) for the quantification of sugars. The HPLC system consisted of an AS50 auto injector, degassing module, GS50 gradient pump, LC30 chromatography oven and UV detector. Chromatographic separation was achieved using a $250 \times 4 \mathrm{~mm}$ Aminex HPX-87C column (Milford). Gradient separations were carried out using aqueous $0.05 \%(\mathrm{v} / \mathrm{v})$ phosphoric acid $(\mathrm{pH} 2$ 2.3) and water: acetonitrile (10:90) as the A and B solvents, respectively. Additional parameters were: injection volume, $25 \mu \mathrm{l}$, column temperature, $30^{\circ} \mathrm{C}$ flow rate, $1 \mathrm{ml} / \mathrm{min}$ and detection wavelength at $210 \mathrm{~nm}$. The xylose and xylooligosaccharides (xylobiose, (1)xylotriose, xylotetraose, xylopentaose and xylohexaose) were eluted out with their gradients. For detection of sugars Refractive Index (RI) detector was used. Their retention time was compared with the external standards.

\section{RESULTS}

The cost of an enzyme is one of the main factors determining the economics of a process, to overcome this problem by optimization of fermentation medium is a good method. The proximate analysis of fruit waste is presented in Table 1. The 
total carbohydrate content is higher in custard apple compared to pomegranate peel due to the higher cellulosic content of custard apple. The untreated corn cobs were composed of a cellulose $(42.8 \pm 0.06)$, hemicellulose $(37.2 \pm 0.3)$, lignin $(5.9 \pm 0.5)$, protein $(3.79 \pm 0.2)$, moisture $(7.0 \pm 0.4)$ and ash $(7.1 \pm 0.2)$. Wherea pretreated corn cobs contained cellulose $(40.4 \pm 0.1)$, hemicelluloses $(21.9 \pm 0.3)$, lignin $(2.56 \pm 0.4$, protein $(4.17 \pm 0.3)$, moisture $(4.8 \pm 1.4)$ and ash $(9.8 \pm 0.8)$ as studied previously (Ramesh et al., 2014).

Table 1 Proximate analysis and composition of fruit peels (Based on dry weight basis \%)

\begin{tabular}{lllllll}
\hline Substrates & Moisture & Ash & $\begin{array}{l}\text { Crude } \\
\text { protein }\end{array}$ & $\begin{array}{l}\text { Crude } \\
\text { fiber }\end{array}$ & Crude fat & $\begin{array}{l}\text { Total } \\
\text { carbohydrates }\end{array}$ \\
\hline \hline Custard apple peel & $93.2 \pm 0.02$ & $1.22 \pm 0.02$ & $1.06 \pm 0.04$ & $3.49 \pm 0.05$ & $0.7 \pm 0.06$ & $19.3 \pm 0.04$ \\
Pomegranate peel & $82.4 \pm 0.03$ & $4.3 \pm 0.06$ & $2.36 \pm 0.07$ & $4.40 \pm 0.06$ & $0.9 \pm 0.02$ & $16.47 \pm 0.03$ \\
\hline \hline
\end{tabular}

Note: The experiments were performed in triplicate.

The enzyme profile revealed that the fungi produced endoxylanase and no cellulase. Hence endoxylanase was further evaluated for mango juice processing An economical process is required for bulk production and industrial application. Hence, a statistical method is used for enhanced production of endoxylanase by T. koeningi under SSF using corn cobs with supplementation of fruit peel as a cost effective substrate.

\section{Optimization of endoxylanase production by using CCD}

The SSF was carried out according to the experimental design model for 5 days In order to increase the enzyme production by fungi in SSF, the medium was supplemented with different medium ingredients. In the present study five variables such as custard apple peel, pomegranate peel, $\mathrm{KH}_{2} \mathrm{PO}_{4},\left(\mathrm{NH}_{4}\right)_{2} \mathrm{SO}_{4}$ and $\mathrm{MgSO}_{4}$ were optimized through the statistical design experiments. Actual and coded levels of variables along with response variables for CCD for the optimization of medium components are presented in Table S1. The CCD was employed to analyze the interactive effect of these parameters and to arrive at an optimum parameter.

In a RSM based approach, the CCD is used for optimization of endoxylanase production by conducting 50 experimental runs with different combinations of the five factors. On the basis of quadratic polynomial equation of response model (Eq.1), the present data not only explains the optimum conditions for enzyme activity but also showed combined effect of independent variables such as custard apple peel, pomegranate peel, $\mathrm{KH}_{2} \mathrm{PO}_{4},\left(\mathrm{NH}_{4}\right)_{2} \mathrm{SO}_{4}$ and $\mathrm{MgSO}$ concentration on endoxylanase activity. The experimental responses along with predicted response calculated from the regression equation (Eq. 4) for each run are shown in Table $\mathrm{S} 2$.

The data was analyzed by multiple regression analysis, and the regression coefficients were determined. A second order polynomial equation (Eq.3) was derived to represent the endoxylanase production as a function of independent variables tested.

$\mathrm{Y}=1847.93+219.55 \mathrm{X}_{1}+198.37 \mathrm{X}_{2}+88.49 \mathrm{X}_{3}+69.72 \mathrm{X}_{4}+47.11 \mathrm{X}_{5}$ $151.16 X_{1}^{2}-164.86 X_{2}^{2}-159.64 X_{3}^{2}-216.30 X_{4}^{2}-259.70 X_{5}^{2}-45.16 X_{1} X_{2}+$ $55.84 X_{1} X_{3}+18.03 X_{1} X_{4}+93.66 X_{1} X_{5}-30.28 X_{2} X_{3}+18.34 X_{2} X_{4}+48.91 X_{2} X_{5}$ $+30.47 \mathrm{X}_{3} \mathrm{X}_{4}+18.66 \mathrm{X}_{3} \mathrm{X}_{5}+1.78 \mathrm{X}_{4} \mathrm{X}_{5}$

Where $\mathrm{Y}=$ Predicted response (xylanase, $\mathrm{U} / \mathrm{gds}$ ), $\mathrm{X}_{1}, \mathrm{X}_{2}, \mathrm{X}_{3}, \mathrm{X}_{4}$ and $\mathrm{X}_{5}$ are coded values of independent variables such as custard apple peel $(\mathrm{g} / \mathrm{l})$, Pomegranate peel $(\mathrm{g} / \mathrm{l}), \mathrm{KH}_{2} \mathrm{PO}_{4}(\mathrm{~g} / \mathrm{l}),\left(\mathrm{NH}_{4}\right)_{2} \mathrm{SO}_{4}(\mathrm{~g} / \mathrm{l})$ and $\mathrm{MgSO}_{4}(\mathrm{~g} / \mathrm{l})$, respectively.

The high value of 219.55 for linear coefficient of custard apple peel (Eq.4) illustrates the significant, positive effect of variable on the endoxylanase activity. The high value of 198.37 for linear coefficient of pomegranate peel shows the positive effect of variable on the enzyme activity. Linear coefficient indicates the enzyme activity increased with custard apple and pomegranate peel than $\mathrm{MgSO}_{4}$ concentration, indicated less $\mathrm{MgSO}_{4}$ is required. The low ranged linear coefficient of other variables demonstrates an increase in enzyme activity, with raises of these variables initially in the ranged assay. The low ranged coefficient for variables indicates the existence of maximum activity to a point; beyond that the entire variable had an inhibitory effect on enzyme activity.

ANOVA is important in determining the adequacy and significance of the quadratic model. Statistical testing of the model was undertaken by means of Fisher's statistical test for ANOVA using Design-expert software and the results are presented in Table S3. The value of coefficient $\mathrm{R}^{2}$ is 0.9147 , which indicated that model could explain $91.47 \%$ of variability and unable to explain only $9.53 \%$ of the total variation. This unexplained value of response was presented in terms of residual errors in the ANOVA Table S3.

The closer the value of $\mathrm{R}^{2}$ to 1 indicate the better correlation between the observed and predicted values. A lower value for the coefficient of variation $9.41 \%$ clearly indicate high degree of precision and higher reliability of the experimental values. Table 4 also gives the $P$ values of each of the variables and their quadratic and interaction terms. The significance of individual variables can be evaluated from their $P$ values, the more significant terms having a lower $P$ value. Values of "Prob $>F$ " less than 0.05 indicate model terms are significant.

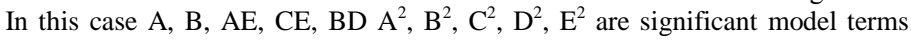
Values greater than 0.10 indicate the model terms are not significant (Designexpert, 2013). The natural logarithm (ln) of the residual SS (sum of square) against $\lambda$ is one, dip suddenly with a minimum in the region of the best optimum value 0.99 . The data do not require a transformation, as current value of confidence interval it contains $(\lambda)$ is very close to the optimum value. The model shows the minimum and maximum confidence interval value with 0.39 and 1.63 respectively (Figure $\mathrm{S} 1$ )

\section{Effect of custard apple peel and $\mathrm{MgSO}_{4}$ on endoxylanase production}

The production of xylanase was significantly influenced by the custard apple peel $(\mathrm{P}<0.005)$ and the custard apple peel $(P<0.005)$ in interaction terms. The custard apple peel $(P<0.005)$ and $\mathrm{MgSO}_{4}$ were $(P<0.005)$ significant in terms of squard terms. The negative interactive coefficient (Eq.4) suggests that decreasing the level increases the enzyme activity while custard apple peel at $5.5 \mathrm{~g} / \mathrm{l}$. The Figure S2 shows optimal xylanase activity ( $3242.43 \mathrm{U} / \mathrm{gds}$ ) could be obtained when the $\mathrm{MgSO}_{4}$ concentration in the range of 5 to $6 \mathrm{~g} / \mathrm{l}$. The remaining varialbles at their optimal level support the enzyme production. Increasing or decreasing the $\mathrm{MgSO}_{4}$ leads to decreasing the enzyme activity due to unstability of the enzyme activity at different $\mathrm{MgSO}_{4}$ concentration.

\section{Effect of pomegranate peel and $\left(\mathrm{NH}_{4}\right)_{2} \mathrm{SO}_{4}$ on endoxylanase production}

The endoxylanase production was influenced by the pomegranate peel in linear term $(P<0.005)$ as well as $\left(\mathrm{NH}_{4}\right)_{2} \mathrm{SO}_{4}(P<0.005)$ and pomegranate peel $(P<0.005)$ in squared terms. There is significant interaction $(P<0.05)$ between these two parameters to obtain optimal enzyme activity. The Figure S3 showed that the maximum endoxylanase activity could be obtained when the pomegranate peel was at $4 \mathrm{~g} / \mathrm{l}$ and the concentration of $\left(\mathrm{NH}_{4}\right)_{2} \mathrm{SO}_{4}$ at $8 \mathrm{~g} / \mathrm{l}$. The positive interaction coefficient of these variables (Eq.4) on the endoxylanase activity is a function of these variables observed by keeping other variables at fixed level which indicated that the higher level of both gave a smaller response. The maximum enzyme activity was $1783.56 \mathrm{U} / \mathrm{gds}$.

\section{Effect of $\mathrm{KH}_{2} \mathrm{PO}_{4}$ and $\mathrm{MgSO}_{4}$ on endoxylanase production}

The enzyme production was influenced by the $\mathrm{KH}_{2} \mathrm{PO}_{4}$ in linear term $(P>0.05)$ and $\mathrm{MgSO}_{4}(P>0.05)$ though their individual $P$ value is not significant. However, both $\mathrm{KH}_{2} \mathrm{PO}_{4}$ and $\mathrm{MgSO}_{4}(P<0.005)$ are having significant squared terms and they showed significant interaction between these two variables should influence on the endoxylanase production (Table 4). The positive interactive coefficien (Eq.4) of these two variables suggested that the enzyme activity was significantly influenced by these variables by fixing other variables at their fixed levels. The Figure S4 showed that optimal xylanase activity could be obtained when the $\mathrm{KH}_{2} \mathrm{PO}_{4}$ was in the range of 1 to $2 \mathrm{~g} / \mathrm{l}$, and the $\mathrm{MgSO}_{4}$ levels between 3 to $4 \mathrm{~g} / \mathrm{l}$, at the optimal level of 2.0. The maximum yield of enzyme activity was 1946.08 U/gds.

\section{Model validation}

The competence of the model was validated by performing a total three verification experiments within the experimental range as given in Table S4. The data of the validation runs were also statistically analyzed to find out the correlation between observed actual and predicted values. The experimental and predicted coefficient of correlation $\left(\mathrm{R}^{2}\right)$ value was found to be 0.9263 indicating that the group of experimental values is in good agreement with that of predicted showing the exactness of the model.

\section{Optimization of mango juice clarification}

The range of temperature chosen to determine the effect of time and temperature on mango juice clarification was 35 to $50^{\circ} \mathrm{C}$. Maximum amount of juice clarification was observed at $40^{\circ} \mathrm{C}$ and $56 \mathrm{~h}$, juice gave $43.4 \%$ increase in clarity in case of Totapuri. The juice from Baneshan after treating with endoxylanase showed maximum clarity at $40^{\circ} \mathrm{C}$ and $56 \mathrm{~h}$, juice was found to be $51.7 \%$ clear (Figure 1). Reducing sugars were found to increase with time and then became 
constant. In case of Totapuri the value of reducing sugars was maximum 84 $\mathrm{mg} / \mathrm{ml}$ in untreated juice and $102.6 \mathrm{mg} / \mathrm{ml}$ in enzyme treated juice at $56 \mathrm{~h}$ after this time they became constant. In case of Baneshan juice treated with enzyme the maximum reducing sugars were formed at $52 \mathrm{~h}$, with concentration 121.1 $\mathrm{mg} / \mathrm{ml}$ while that of untreated juice it was only $98.3 \mathrm{mg} / \mathrm{ml}$ (Figure 2).

The enzyme dose was optimized to be $9.0 \mathrm{U}$ for Baneshan juice with maximum flow rate of $8 \mathrm{ml} / \mathrm{min}$ and $12.0 \mathrm{U}$ with maximum flow rate of $6 \mathrm{ml} / \mathrm{min}$ for Totapuri juice (Figure 3).

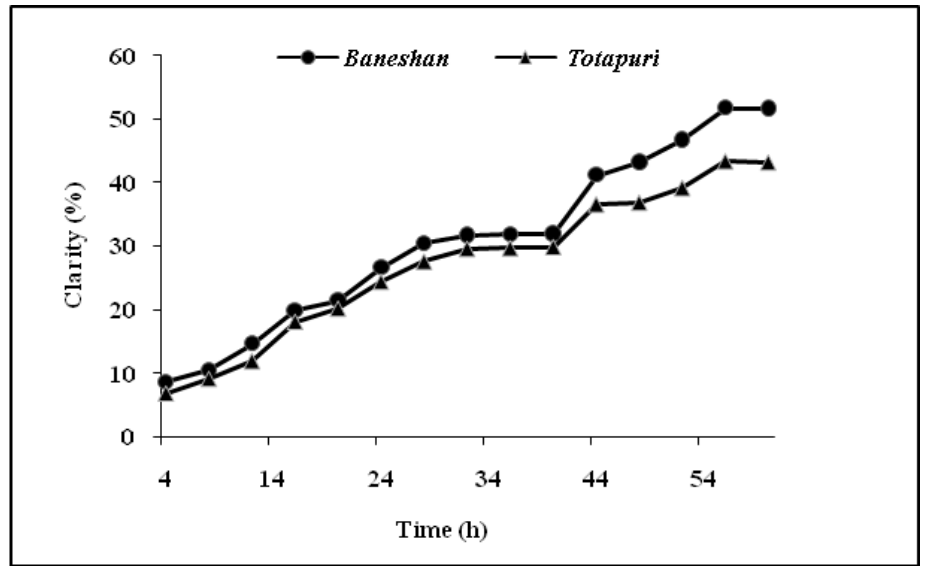

Figure 1 Optimization of endoxylanase incubation time on mango juice clarification.

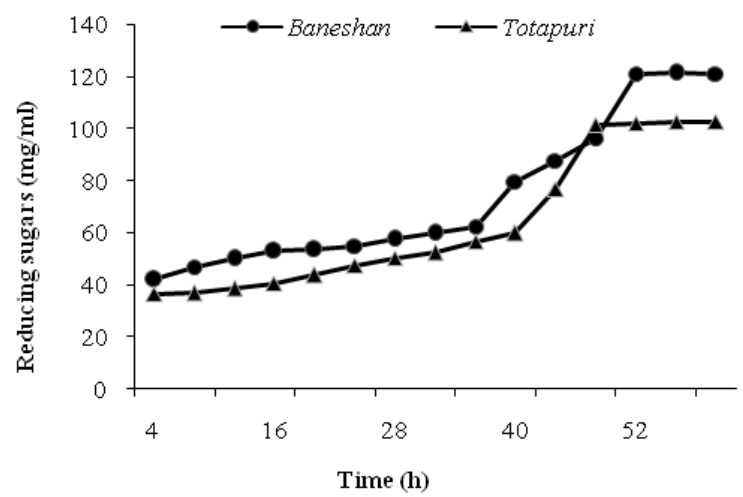

Figure 2 Optimization of endoxylanase incubation time on mango juice reducing sugars.

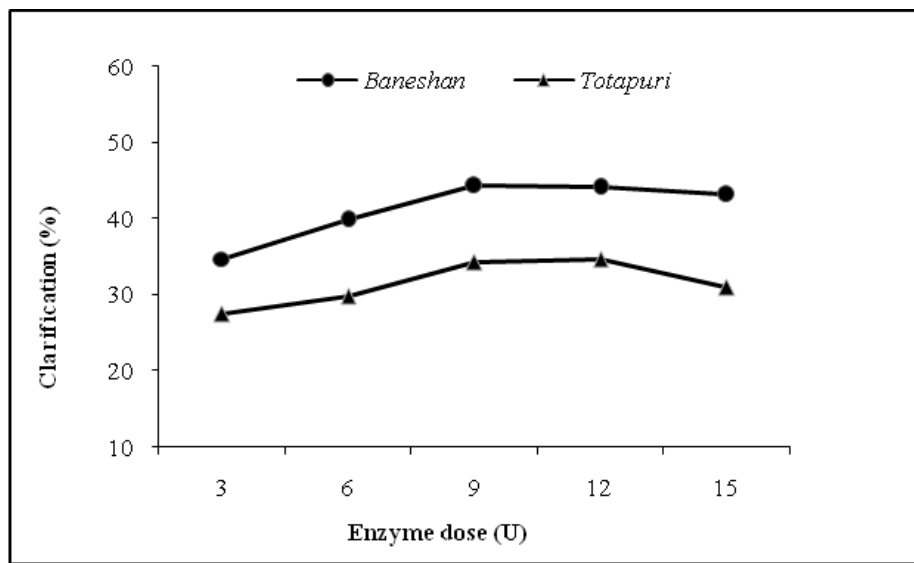

Figure 3 Optimization of endoxylanase dose on mango juice clarification.

\section{Clarification of mango juices by endoxylanase}

The clarified Baneshan and Totapuri juice products were quantified by the HPLC. The Figure 4 and 5 shows the quantification of released products of xylooligosaccharides [RT-9.5 xylose $(2.0 \mathrm{mg} / \mathrm{ml})$, RT-7.5 xylobiose $(1 . .3 \mathrm{mg} / \mathrm{ml})$ RT-6.3 xylotriose $(0.6 \mathrm{mg} / \mathrm{ml})$, RT-9.8 xylohexaose $(0.3 \mathrm{mg} / \mathrm{ml})$ and (RT-9.3 xylose $(2.6 \mathrm{mg} / \mathrm{ml})$, RT-7.9 xylobiose $(2.0 \mathrm{mg} / \mathrm{ml})$, RT-6.6 xylotriose $(1.1$ $\mathrm{mg} / \mathrm{ml})$, RT-9.9 xylohexaose $(0.6 \mathrm{mg} / \mathrm{ml})]$. Up to $56 \mathrm{~h}$ incubation maximum sugars were observed, but beyond $56 \mathrm{~h}$ there was constant amount of sugars due to the availability or incomplete clarification of juices.

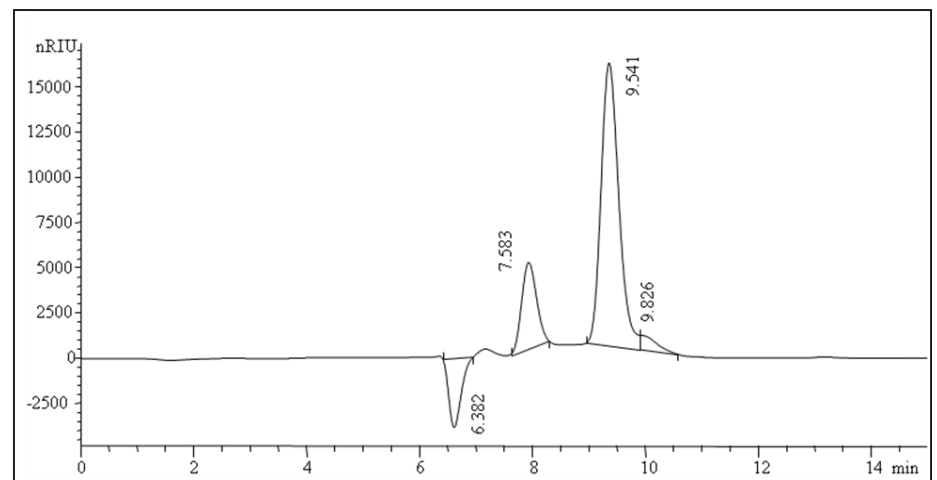

Figure 4 HPLC chromatogram showing endoxylanase treated Totapuri juice products

(RT-9.5 xylose, RT-7.5 xylobiose, RT-6.3 xylotriose, RT-9.8 xylohexaose)

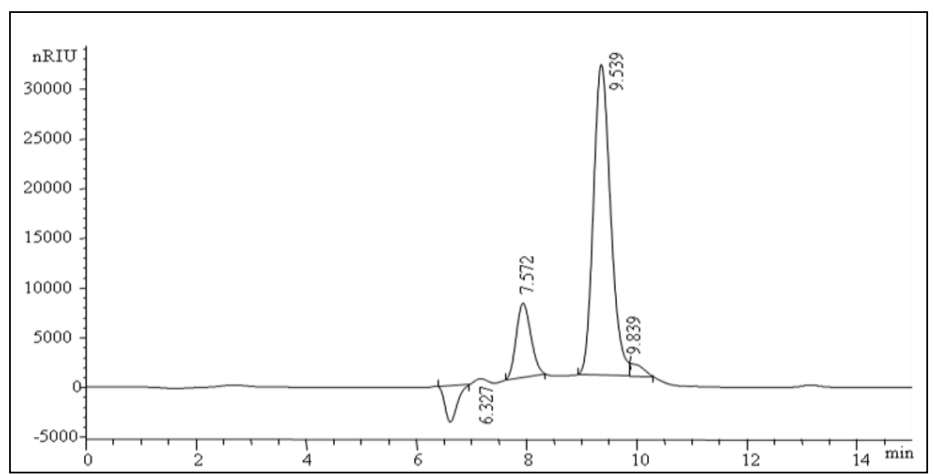

Figure 5 HPLC chromatogram showing endoxylanase treated Baneshan juice products.

(RT-9.5 xylose, RT-7.5 xylobiose, RT-6.3 xylotriose, RT-9.8 xylohexaose

\section{DISCUSSION}

The production of endoxylanase by $T$. koeningi has been studied in this laboratory. Corn cob is the central part of maize commonly disposed in open or burnt, leading to its non usability as well as causing environmental concern. Therefore it will be of interest to use corn cob for chemical and biological processing to obtain end products with added values at very low price (Kumar $\boldsymbol{e t}$ al., 2010). The optimization was done with the supplementation of custard apple peel, pomegranate peel, $\mathrm{KH}_{2} \mathrm{PO}_{4},\left(\mathrm{NH}_{4}\right)_{2} \mathrm{SO}_{4}$ and $\mathrm{MgSO}_{4}$. This particular fungus is of interest because it produces a high amount of endoxylanase in SSF compare to other Trichoderma sp. Earlier we have reported the optimization of conditions for increased xylanase production using co-cultures of T. koeningi and Sclertium rolfsii (Ramesh and Reddy, 2013). The optimization of xylanase production process often presents a situation, in which several variables need to be considered and yet the relative importance of each is still not known. In this study the variables, custard apple peel and pomegranate peel powder concentrations with their interactive $\mathrm{KH}_{2} \mathrm{PO}_{4},\left(\mathrm{NH}_{4}\right)_{2} \mathrm{SO}_{4}$ and $\mathrm{MgSO}_{4}$ nutrients had the most important effects on xylanase production. Increasing the custard apple peel and decreasing $\mathrm{MgSO}_{4}$ in the $\mathrm{SSF}$ process, increased the xylanase activity. Indeed, for fermentation we propose reducing the chemical carbon and use the natural organic decomposed peel powder in the fermentation, since these variables were significant in case of pomegranate peel and $\left(\mathrm{NH}_{4}\right)_{2} \mathrm{SO}_{4}$ were positive interaction on xylanase production and gave maximum production of $1783.56 \mathrm{U} / \mathrm{gds}$. The variables $\mathrm{KH}_{2} \mathrm{PO}_{4}$ and $\left(\mathrm{NH}_{4}\right)_{2} \mathrm{SO}_{4}$ were proportional to endoxylanase production, but $\mathrm{MgSO}_{4}$ was inversely proportional to production of endoxylanase.

The endoxylanase activity obtained in this study was compared with reference data for similar species. A detailed analysis of xylanase production by $T$. aurantiacus using beet juice was carried out by Grajek et al. (1987) but 26 times less xylanase activity was observed. Biswas et al. (1988) studied the production of xylanase using wheat bran and sugar cane bagasse in solid medium with Aspergillus ochraceus and found that the bagasse gave lower yields than the wheat bran. From their results it can be concluded that the xylanase activity of several fungal species is directly related to the composition of the culture medium, cultivation conditions and to the recovery of the enzyme from the medium. The utilization of solid lignocellulosic substrates for large-scale xylanase production has proved economically viable. However, the development of SSF process with high productivity requires a set of controlled variables for $T$. koeningi.

The efficacy of xylanase was studied on juice enrichment of apples (Malus domestica), pineapples (Ananas comosus L.) and tomatos (Lycopersicum esculentum). The treatment with xylanase led to an increase juice yield by 23.53 (apple), 10.78 (pineapple) and $20.78 \%$ (tomato) as well as having a significant effect on juice clarity by an increase of $\%$ transmittance of $22.20,19.80$ and 
14.30, respectively. The turbidity and viscosity was also decreased without affecting acid neutrality significantly (Sushil $\boldsymbol{e t}$ al., 2012). Olfa (2007) reported clarification in the apple juice by use of xylanase from Bacillus pumulis MTCC 8964 at $24^{\circ} \mathrm{C}$ and ambient room temperature. In the present study mango juice clarification was studied using endoxylanase (Figure 7). There was better \% clarification in case of Baneshan than in Totapuri mango juice may be due to less thickness of Baneshan tissue than Totapuri. Endoxylanase has been already reported to clarify fruit juices by $27 \%$ (Salunk et al., 1984). The maximum reducing sugars were produced in the Totapuri $(102.6 \mathrm{mg} / \mathrm{ml})$ and Baneshan $(121.1 \mathrm{mg} / \mathrm{ml})$ when compared to the untreated juices ( 84 and $98.3 \mathrm{mg} / \mathrm{ml}$ ). Similarly Pseudomonas sp. xylanase has resulted in improvement of reducing sugars $54.5 \mathrm{mg} / \mathrm{ml}$ in $16 \mathrm{~h}$ and $42.14 \%$ clarity of mausambi juice. In case of orange juice, enzyme treated juice gave maximum reducing sugars $146 \mathrm{mg} / \mathrm{ml}$ at $52 \mathrm{~h}$ while that of untreated juice it was only $84 \mathrm{mg} / \mathrm{ml}$ (Kumar et al., 2009) The permeability of the sample depended on the thickness or rigidity, if the thickness is high filterability of the sample is low, at the same time thickness is low filterability of the sample is high. Based on fundamental principle, untreated mango juice thickness is very high but in the enzyme treated juice thickness is low, and filterability was high both varieties of mango fruits. Sharma et al. (2012) reported that mausambi juice treated with optimized $8 \mathrm{U}$ enzyme dose gave the maximum flow rate of $6 \mathrm{ml} / \mathrm{min}$. In case of orange juice $8.06 \mathrm{U}$ enzyme dose gave a flow rate of $0.9 \mathrm{ml} / \mathrm{min}$. Filterability was maximum at optimized enzyme dose as it clarified the juice greater improved its filterability because of disruption of hemicelluloses and hydrolysis of polymeric carbohydrates of juice, which enhanced the extent of liquefaction of fruit juice, which made it more permeable across filter.

\section{CONCLUSION}

The present central composite design and regression analysis report clearly shows that the supplementation of custard apple peel and pomegranate peel to fermentation medium helped to increase the endoxylanase production by the $T$. koeningi isolate in solid state fermentation. The model predicted endoxylanase production of $2257.58 \mathrm{U} / \mathrm{g}$ with the actual yield of $2242.43 \mathrm{U} / \mathrm{g}$ from pretreated corn cob, which indicates more than two fold improvement of enzyme production. The results on treated mango juice clearly indicates its use in the juice clarification. From these results it can concluded that the produced endoxylanase may be useful in the mango fruit juice processing industries.

Acknowledgments: We are thankful to Dr. S.C. Basappa, former Deputy Director and Scientist, Central Food Technological Research Institute (CFTRI), Mysore, for his encouragement and critical comments on the manuscript.

\section{REFERENCES}

AOAC (1990) Official methods of analysis. $18^{\text {th }}$ edition: 47.

AWAFO, V.A., CHAHAL, D.S., SIMPSON, B.K. 2000. Evaluation of combination treatments of sodium hydroxide and steam explosion for the production of cellulase-systems by two Trichoderma reesei mutants under solidstate fermentation conditions. Bioresource Technology, 73, 235-245. http://dx.doi.org/10.1016/S0960-8524(99)00149-2

BAILEY, M.J., BIELY, P., POUTANEN, K. 1992. Interlaboratory testing of method for assay of xylanase activity. Journal of Biotechnology. 23, 257-270. http://dx.doi.org/10.1016/0168-1656(92)90074-j

BISWAS, S.R., MISHRA, A.K., NANDA, G. 1988. Xylanase and $\beta$-xylosidase production by Aspergillus ochraceus during growth on lignocelluloses. Biotechnology and Bioengineering, 31, 613-616. http://dx.doi.org/10.1002/bit.260310614

BOX, G.E.P., BENHNKEN, D.W. 1960. Some new three level design for the study of quantitative variable. Technometrics, 2, 455-475.

CYRAN, M.R., SAULNIER, L. 2007. Association and structural diversity of hemicelluloses in the cell walls of rye outer layers: Comparison between two ryes with opposite bread making quality. Journal of Agriculture and Food Chemistry, 55, 2329-2341. http://dx.doi.org/10.1021/jf062473g

DUBOIS, M., GILLES, K.A., HAMILTON, J.K., REBERS, P.A., SMITH, F. 1956. Colorimetric method for determination of sugars and related substances. Analytical Chemistry, 26, 350. http://dx.doi.org/10.1021/ac60111a017

GOERING, H.K., VAN SOEST, P.J. 1970. Forage fibre analysis.Agricultural Handbook No.379.

GRAJEK, W.1987. Production of D-xylanases by thermophilic fungi using different methods of culture. Biotechnology Letters, 9(5), 353-356. http://dx.doi.org/10.1007/BF01025803

HALTRICH, D., NIDETZKY, B., KULBE, K.D., STEINER, W., ZUPANCIC S. 1996. Production of fungal xylanases. Bioresource Technology, 58,137-161 http://dx.doi.org/10.1016/s0960-8524(96)00094-6

INGLETT, G.E. 1970. Corn: Culture Processing and Products, AVI Publishing Co, Westport, CT (USA).

JEYA, M., ZHANG, Y.W., KIM, I.W., LEE, J.K. 2009. Enhanced saccharification of alkali-treated rice straw by cellulase from trametes hirsuta and statically optimization of hydrolysis conditions by RSM. Bioresource Technology, 100, 5155-5161. http://dx.doi.org/10.1016/j.bortech.2009.05.04

KALOGERIS, E., CHRISTAKOPOULOS, P., KEKOS, D., MACRIS, B.J. 1998. Studies on the solid-state production of thermostable endo xylanases from Thermoascus aurantiacus: characterization of two isozymes. Journal of Biotechnology, 60,155-163. http://dx.doi.org/10.1016/s0168-1656(97)00186-7 KHURANA, S., KAPOOR, M., GUPTA, S., KUHAD, R.C. 2007. Statistical optimization of alkaline xylanase production from Streptomyces violaceoruber under submerged fermentation using response surface methodology. Indian Journal of Microbiology, 47, 144-152. http://dx.doi.org/10.1007/s12088-0070028-4

KUMAR, D., VERMA, R., SAVITRI, D., BHALLA, T.C. 2009. Immobilization of xylanase produced by new isolate Bacillus pumilus MTCC 8964. Int Conf Bioencap Groningen, Nether land, 1-4.

KUMAR, S., UPADHYAYA, J.S., YUVRAJ, S.N. 2010. Preparation of nanoparticules from corncobs by chemical treatment methods. Bioresource Technology, 5, 1292-1300.

LATIFIAN, M., HAMIDI-ESFAHANI, Z., BARZEGAR, M. 2007. Evaluation of culture conditions for cellulase production by two Trichoderma reesei mutants under solid-state fermentation conditions. Bioresource Technology, 98, 36343637. http://dx.doi.org//10.1016/j.biortech. 2006.11.019

MAHESHWARI, R., BHARADWAJ, G., BHAT, M.K. 2000. Thermophilic fungi: their physiology and enzymes. Microbiology and Molecular Biology Reviews, 64,461-488. http://dx.doi.org//10.1128/MMBR.

MILLER, G.L. 1959. Use of dinitrosalicylic acid reagent for determination of $\begin{array}{llll}\text { reducing } & \text { sugar. } & \text { Analytical } & \text { Chemistry, }\end{array}$ http://dx.doi.org//10.1021/ac60147a030

OLFA, E., MONDHER, M., ISSAM, S., FERID, L., NEJIB, M.M. 2007. Induction properties and application of xylanase activity from Sclerotinia sclerotiorum S2 fungus. Journal of Food Biochemistry. 31, 96-107. http://dx.doi.org//10.1111/j.1745-4514.2007.00101.x

OWEN, N.L., THOMAS, D.W. 1989. Infrared studies of hard and soft woods Applied Spectroscopy, 43, 451-455.

PARK, Y., KANG, S., LEE, J., HONG, S., KIM, S. 2002. Xylanase production in solid state fermentation by Aspergillus niger mutant using statistica experimental designs. Applied Microbiology and Biotechnology, 58, 761-766. http://dx.doi.org//10.1007/s00253-002-0965-0

RAMESH, B., VIJAYA KUMAR, P., REDDY, O.V.S. 2014. Enhanced production of xylanase by solid state fermentation using Trichoderma koening isolate: effect of pretreated agro-residues, 3 Biotech, 4, 655-664 http://dx.doi.org//10.1007/s13205-014-0239-4.

RAMESH, B., REDDY, O.V.S. 2013. Selection of co-cultures for production of cellulase free-xylanase using agro waste and optimization of cultural conditions by response surface methodology and Box-behnken design. International Journal of Current Microbiology and Applied Sciences, 2, 418-434.

RENE, E.R., JO, M.S., KIM, S.H., PARK, H.S. 2007. Statistical analysis of main and interaction effects during the removal of BTEX mixtures in batch conditions, using peel water treatment plant sludge microbes. International Journal of Environmental Science and Technology, 4, 177-182.

ROMANOWSKA, I., POLAK, J., BIELECKI, S. 2006. Isolation and properties of Aspergillus niger IBT-90 xylanase for bakery. Applied Microbiology and Biotechnology, 69, 665-671. http://dx.doi.org//10.1007/s00253-005-0011-0

SHARMA, H., CHAND, T. 2012. Pseudomonas sp. xylanase for clarification of mausambi and orange fruit pulp. International Journal of Advancements in Research and Technology, 1, 24-29.

SOKHANSANJ, S., TURHOLLOW, A., CUSHMAN, J., CUNDIFF, J. 2002. Engineering aspects of collecting corn stover for bioenergy. Biomass and Bioenergy, 23, 347-355. http://dx.doi.org/10.1016/s0961-9534(02)00063-6

SUSHIL, N., ANURADHA, M., VIJAY KUMAR, G. 2012. Enzymatic clarification of fruit pulps (apple, pineapple and tomato) using purified Bacillus pumilus SV-85S xylanase. Biotechnology and Bioprocess Engineering, 17, 1165 1175. http://dx.doi.org/10.1007/s12257-012-0375-9

SZEGHALMI, A., KAMINSKYJ, S., GOUGH, K.M. 2007. A synchrotron FTIR microspectroscopy investigation of fungal hyphae grown under optimal and stressed conditions. Analytical and Bioanalytical Chemistry, 387, 1779-1789. http://dx.doi.org/10.1007/s00216-006-0850-2

VIIKARI, L., KANTELINEN, A., SUNDQVIST, J., LINKO, M. 2001. Xylanases in bleaching: from an idea to the industry. FEMS Microbiology Reviews, 13, 335-350. http://dx.doi.org/10.1111/j.1574-6976.1994.tb00053.x WANG, S.L., YEN, Y.H., SHIH, I.L., CHANG, A.C., CHANG, W.T., WU, W.C., CHAI, Y.D. 2003. Prodcution of xylanases from rice bran by Streptomyces actuosus A-151. Enzyme Microbial Technology, 33, 917-925. 